\title{
Prevalence and Determinants of Fatigue among Private High School Students in Bogor Tengah Sub-District, Indonesia, 2016
}

\author{
Basuki Rachmat* and Andi Susilowati \\ National Institute of Research and Development, Ministry of Health of Republic of Indonesia, Jakarta, Indonesia; \\ basukir2009@gmail.com
}

\begin{abstract}
Background: Student performance determines learning achievement and how students absorb lessons in class. One of the factors that cause student performance to decline is physical fatigue, which arises because of the classroom's physical environment that does not support the teaching and learning process. Purpose: This study was conducted to determine the relationship between classroom's physical environmental conditions and fatigue among high school students. Methods: The study design used was cross-sectional. Data collection included measurements of physical environmental parameters (humidity, temperature, lighting, noise, air flow, ventilation, temperature control, room capacity, room area ratio per person, and school location) and measurements of fatigue among students using the Subjective Self Rating Test in the form of questionnaire. Total sample was 448 students in 10 private high schools, with inclusion criteria: the students are not sick in the last two weeks and $10^{\text {th }}$ and $11^{\text {th }}$ grade students from 10 private high schools. Results: The research showed classroom's physical environmental factors that affect fatigue among student's included temperature, relative humidity, air flow, and air conditioner. While the most dominant indicator that was related to the occurrence of students' fatigue was sex. Conclusion: Further research is needed on other factors that may cause fatigue among students in the classroom to support the conclusion of this research.
\end{abstract}

Keywords: Fatigue, Physical Environment, Private High School

\section{Introduction}

The physical environmental condition of a room can be measured and controlled so that the room becomes comfortable for people inside it. The physical environmental factors of a room comprise of: room capacity, ratio of space needed per person, temperature, relative humidity, lighting, noise level, air flow, availability of air conditioning tools (fan or air conditioner), and ventilation. Physical and external environmental indicators have an impact on user comfort, including comfort in indoor air quality, thermal comfort, visual comfort, acoustic comfort and ergonomic comfort ${ }^{1}$.

The need to achieve a good level of comfort in commercial buildings and education is very important, because in fact, some people spend more than $90 \%$ of their time indoors, and about $30 \%$ of their time at school ${ }^{2}$.
A study in England explored the environmental conditions of classrooms in newly built secondary schools. Indicators used in this study were indoor air quality, thermal comfort and acoustic performance. This study showed that in schools with mechanical ventilation, there was still a level of internal environmental noise, while the thermal comfort was acceptable, but the temperature tended to be much higher in practice, compared to what was desired $\stackrel{3}{\text {. }}$.

The physical environmental condition of a school is an important matter and becomes one of the determining factors that can affect the health condition, behavior, and student achievement $t^{4,5}$. The poor quality of classroom's indoor environment was thought to affect students' health, comfort, attendance and academic performance ${ }^{6}$. Standard physical environment parameters in Indonesia related to classroom include: a minimum ratio of $2 \mathrm{~m}^{2}$ class area/learner, lighting (a minimum 
of 100 Lux), a maximum noise level of $85 \mathrm{~dB}$, good ventilation holes at least $15 \%$ of the floor surface area of the room, temperature $18^{\circ} \mathrm{C}$ to $28^{\circ} \mathrm{C}$, air humidity $40 \%-60 \%(\mathrm{RH})$, air flow $\geq 0.15 \mathrm{~m} / \mathrm{s}$, room capacity $<30$ people, air conditioner, school location ${ }^{\frac{7-9}{}}$.

Another study focused on understanding the perceptions of thermal comfort and behavior characteristics of students in the classroom. Thermal comfort surveys were carried out on 4866 primary and secondary school students in Australia for two summers. Research showed that students who hadbeen placed in air-conditioned classrooms were more likely to choose air conditioning as an air source for maintaining their comfort, compared to those accommodated in classrooms without air conditioning ${ }^{10}$.

According to M. Kuru and G. Calis, the physical environmental condition of a room could lead to weariness or fatigue ${ }^{11}$. Fatigue is a physiological phenomenon arises after an activity that requires concentration or physical effort. It is a mechanism for protecting the body to avoid further damage and usually will recover after a break $\frac{12-14}{}$. Fatigue can be classified into three types: weakening activities, weakening motivation, and physical fatigue $\frac{15,16}{}$. For students, fatigue can lead to a decline in school performance, negative health outcomes, and refusal to attend school ${ }^{17}$.

One commonly used measurement of fatigue is the Subjective Self Rating Test (SSRT), which comprises of a number of questions asking about symptoms or feelings that are subjective to someone $e^{14,18}$. A study involving elementary and junior high school students about the relationship of cognitive function with the prevalence of fatigue amongstudents,was conducted. It is known that the development of cognitive functions that depend on values can influence the severity of fatigue among students ${ }^{19}$.

The purpose of this article was to identify determinants related to fatigue among private high school students and to determine the possibility of subgroups in the population that needed a program focus given the importance of supporting comfortable classroom's physical environmental condition in the teaching and learning process. Specifically, this article was to explorethe potential role of the learning space's physical environmental condition to reduce the level of fatigue amongstudents during the learning process in the classroom.

\section{Methods}

This article was the results of data analysis in the 2016 Health-guided Research Study (RISBINKES). The study locations were 18 classrooms from 10 Private High Schools in Bogor Tengah sub-district, with 487 students as respondents. The study was conducted from April to December 2016. This research was conducted during the dry and rainy seasons, in naturally ventilated buildings using the adaptive approach, in accordance with ASHRAE 55/2004, ISO 7730 and ISO 10551. The research design used was cross-sectional. The data used were data from measurements of temperature, humidity, light intensity, noise, air flow, ventilation, availability of air conditioner, room capacity, ratio of room area per person, school location. Temperature, humidity and air flow were measured using an Anemometer ${ }^{20}$. The intensity of light was measured using Lux Meters ${ }^{21}$. Noise was measured using a Sound Level Meter. Measurements of length, width and height of the room were done using a Digital Meter.

Measurement of fatigue among students was done using a scale questionnaire issued by the International Fatigue Research Conference (IFRC) or called the Subjective Self Rating Test (SSRT) which contained 30 questions related to symptoms of fatigue. The answers to the IFRC questionnaire were divided into 4 large categories, which were frequent (SS) with a score of 4 , often (S) with a score of 3 , sometimes $(\mathrm{K})$ with a score of 2 , and never (TP) with a score of 1 . To determine the level of fatigue, the answers to each question were summed then matched with a certain category, a score of 52 (not tired), a score of 53-75 (mild fatigue), a score of 76-98 (moderate fatigue), and a score of 9-120 (severe fatigue) ${ }^{16}$. Data were analyzed using univariate, bivariate and multivariate statistical models to determine the description, relationship and physical environment factors that affected fatigue among students the most. In the analysis of fatigue, it was categorized into two, not tired and tired categories (mild fatigue, moderate fatigue, severe fatigue).

\section{Results}

Based on the results of data analysis, there were 39 people (8\%) from the total sample obtained during the data collection. While student's with healthy condition were 448 people (92\%) of the total sample. So that respondents 
who can be used in the data analysis were 448 people. Based on these data (Table 1) female students were 241 people (52.8\%), with the dominant nutritional status was not obese as many as 385 people (85.9\%). Student's behavior in consuming drinking water in class was carried out by 319 people (71.2\%). The picture of fatigue among students was dominated by students with fatigue condition as many as 252 people $(56.2 \%)$, where fatigue was divided into two categories, 237 people (52.9\%) with mild fatigue and 15 people (3.3\%) with moderate fatigue.

Table 1. Student population characteristics based on sex, nutritional status, breakfast behavior and Drinking water behavior at school $(\mathrm{N}=448)$.

\begin{tabular}{|c|l|l|}
\hline \multicolumn{1}{|c|}{ Factors } & \multicolumn{1}{|c|}{$\begin{array}{c}\text { Number } \\
(\mathbf{N})\end{array}$} & $\begin{array}{c}\text { Proportion } \\
(\%)\end{array}$ \\
\hline Sex & 207 & 46.2 \\
\hline Boys & 241 & 53.8 \\
\hline Girls & & \\
\hline Nutritional status & 57 & 12.1 \\
\hline obese $\left(\geq 25.0 \mathrm{Kg} / \mathrm{m}^{3}\right)$ & 391 & 87.3 \\
\hline not obese $\left(<25,0 \mathrm{Kg} / \mathrm{m}^{3}\right)$ & & \\
\hline Breakfast behavior & 20 & 4.5 \\
\hline No & 448 & 95.5 \\
\hline Yes & & \\
\hline Level of student fatigue & 252 & 56.2 \\
\hline Tired & 196 & 43.8 \\
\hline Not tired & & \\
\hline $\begin{array}{l}\text { Drinking water behavior at } \\
\text { school }\end{array}$ & 129 & 28.8 \\
\hline No & 319 & 71.2 \\
\hline Yes & & \\
\hline
\end{tabular}

Water consumption behavior showed that students who consumed $550 \mathrm{ml}$ of water up to $1000 \mathrm{ml}$ for 7-8 hours in school were 319 people (71.2\%), while the number of students who didnot consume drinking water and drink water less than $550 \mathrm{ml}$ were 129 (28.8\%). Students who did not eat breakfast were 20 people (4.5\%), the reason why they did not to eat breakfast was that there was no food at home, I could not eat too early and I had no time for breakfast.

The minimum surface area of a classroom in the physical environmental characteristics of the classroom (Table 2) was $35.98 \mathrm{~m}^{2}$. This area was still below the minimum standard recommended by the Indonesian government, which was $64 \mathrm{~m}^{2}$. The lowest temperature of 18 classrooms was $27.2^{\circ} \mathrm{C}$, at this temperature the classroom was cool, while the highest temperature was $31.3^{\circ} \mathrm{C}$, which means the room had started to get hot. The lowest value of moisture of the classroom was $59.4 \%$, where the space was moister and cool, while the highest humidity was 84.37 , which means the room was getting hotter. The average noise level of 18 classrooms in 10 high schools in the central Bogor sub-district was $77.75 \mathrm{dBA}$. The lowest noise was $72.2 \mathrm{dBA}$, it was still below the maximum noise threshold value of $85 \mathrm{dBA}$, while the highest noise was 87.18 , which means that the classroom noise value exceeded the maximum noise limit value of $85 \mathrm{dBA}$. The level of lighting in the study room shows that the median level of lighting in 18 classrooms in 10 high schools in Bogor Central district was 128.01 Lux. The lighting level was 26.31, at this lighting level the study room was far below the recommended standard lighting level of 300 Lux.

The air flow shows that the average air rate of 18 classrooms in 10 high schools in Bogor Tengah District was $0.07 \mathrm{~m} / \mathrm{s}$. the lowest air rate was $0.01 \mathrm{~m} / \mathrm{s}$, where the air flow value caused an increase in temperature and humidity so that the air became hot and stuffy, the recommended standard air rate was $0.15 \mathrm{~m} / \mathrm{s}$. In areas with a warm climate, research on thermal comfort indicated that air flow should vary from $0.2 \mathrm{~m} / \mathrm{s}$ to $1.5 \mathrm{~m} / \mathrm{s}$. Air comfort was obtained from air velocities below 0.2 $\mathrm{m} / \mathrm{s}$ in the standard ASHRAE 5522. The need for a ratio of surface area per student in (Table 2) shows that the average ratio of study space per person in 18 classrooms in 10 high schools in Bogor Central District was $1.73 \mathrm{~m}^{2} /$ person, this area was still below the minimum standard recommended by Indonesian government which was $2 \mathrm{~m}^{2} /$ person. The lowest ratio of study space per person was $1.12 \mathrm{~m}^{2} /$ person, the small ratio of the learning space will affect the lack of movement of students, so that it will interfere with the comfort of student learning.

Table 2. Characteristics of Physical Environmental Condition in classrooms in private high schools in Bogor District, Bogor City $(\mathrm{N}=18)$

\begin{tabular}{|l|l|l|l|l|}
\hline Factors & Mean & Median & $\begin{array}{l}\text { Std. } \\
\text { Deviation }\end{array}$ & $\begin{array}{l}\text { Min.- } \\
\text { Max. }\end{array}$ \\
\hline Surface area $\left(\mathrm{m}^{2}\right)$ & 47.53 & 43.79 & 8.05 & $\begin{array}{l}(35.98, \\
61.85)\end{array}$ \\
\hline Temperature $\left({ }^{\circ} \mathrm{C}\right)$ & 29.55 & 29.67 & 1.14 & $\begin{array}{l}(27.42, \\
31.32)\end{array}$ \\
\hline
\end{tabular}




\begin{tabular}{|l|l|l|l|l|}
\hline $\begin{array}{l}\text { Relative Humidity } \\
(\%)\end{array}$ & 70.78 & 9.40 & 6.67 & $\begin{array}{l}(59.40, \\
84.37)\end{array}$ \\
\hline $\begin{array}{l}\text { Light Intensity } \\
\text { (Lux) }\end{array}$ & 128.01 & 109.11 & 83.62 & $\begin{array}{l}(26.31, \\
312.67)\end{array}$ \\
\hline Noise Level (dBA) & 77.80 & 76.30 & 4.67 & $\begin{array}{l}(72.20, \\
87.18)\end{array}$ \\
\hline Air flow (m/s) & 0.07 & 0.06 & 0.05 & $\begin{array}{l}(0.01, \\
0.18)\end{array}$ \\
\hline $\begin{array}{l}\text { Study room ratio } \\
\text { per person (m } / \\
\text { person) }\end{array}$ & 1.73 & 1.67 & 0.36 & $\begin{array}{l}(1.12, \\
2.54)\end{array}$ \\
\hline
\end{tabular}

Table 3 presents the risk factors associated with fatigue. Fatigue was significantly lower among students who stayed in rooms with temperature less than $28^{\circ} \mathrm{C}$, good air flow, adequate air conditioner, and the compatibility of the classroom ratio with the standards set. Opportunities for fatigue were significantly greater among female compared to male. Students with $550 \mathrm{ml}$ to $1000 \mathrm{ml}$ of water consumption behavior for 7-8 hours at school had a significantly lower fatigue than those who did not consume water.

Table 3. Odd Ratio (OR) for risk factors for fatigue among private high school students in central Bogor subdistrict of Bogor $(\mathrm{N}=448)$

\begin{tabular}{|c|c|c|c|c|c|c|c|c|c|}
\hline \multirow{2}{*}{\multicolumn{2}{|c|}{ Factors }} & \multirow{3}{*}{$\begin{array}{l}\text { Fatigue (\%) } \\
66.4 \\
\end{array}$} & \multirow{3}{*}{$\begin{array}{r}\mathbf{N} \\
160 \\
\end{array}$} & \multicolumn{3}{|c|}{ Unadjusted (Bivariate) } & \multicolumn{3}{|c|}{ Adjusted (Multivariate) } \\
\hline & & & & \multirow{2}{*}{\begin{tabular}{|c|} 
OR \\
2.47 \\
\end{tabular}} & \multirow{2}{*}{$\begin{array}{c}\mathbf{9 5 \%} \mathbf{C I} \\
(1.68,3.62)\end{array}$} & \multirow{2}{*}{$\frac{\mathbf{p}}{0.000003}$} & \multirow{2}{*}{$\begin{array}{c}\text { OR } \\
2.67\end{array}$} & \multirow{2}{*}{$\begin{array}{c}\mathbf{9 5 \%} \text { CI } \\
(1.78,3.99)\end{array}$} & \multirow{2}{*}{$\frac{\mathbf{p}}{0.000001}$} \\
\hline Sor & Girls & & & & & & & & \\
\hline 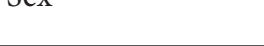 & Boys & 44.4 & 92 & & & & & & \\
\hline \multirow{2}{*}{ Nutritional status } & $\geq 25.0 \mathrm{~kg} / \mathrm{m}^{3}$ & 59.6 & 34 & 1.17 & $(0.67,2.06)$ & 0.68 & & & \\
\hline & $<25,0 \mathrm{~kg} / \mathrm{m}^{3}$ & 55.8 & 218 & & & & & & \\
\hline \multirow{2}{*}{ Relative humidity } & $>60 \%$ & 36.8 & 7 & 0.44 & $(0.17,1.14)$ & 0.13 & 0.30 & $(0.11,0.84)$ & 0.022 \\
\hline & $40-60 \%$ & 57.1 & 245 & & & & & & \\
\hline \multirow{2}{*}{ Temperature } & $>28^{\circ} \mathrm{C}$ & 58.6 & 229 & 2.09 & $(1.19,3.68)$ & 0.014 & 2.25 & $(1.24,4.08)$ & 0.008 \\
\hline & $\leq 28^{\circ} \mathrm{C}$ & 40.4 & 23 & & & & & & \\
\hline \multirow{2}{*}{ Lighting Level } & $<300 \operatorname{Lux}$ & 57.6 & 19 & 1.060 & $(0.52,2.17)$ & 1 & & & \\
\hline & $\geq 300$ Lux & 56.1 & 233 & & & & & & \\
\hline \multirow{2}{*}{ Noise Level } & $>85 \mathrm{dBA}$ & 69.1 & 56 & 1.95 & $(1.17,3.27)$ & 0.014 & & & \\
\hline & $\leq 85 \mathrm{dBA}$ & 53.4 & 196 & & & & & & \\
\hline \multirow{2}{*}{ Air flow } & $<0.15 \mathrm{~m} / \mathrm{s}$ & 52.4 & 207 & 0.19 & $(0.09,0.43)$ & 0.0005 & 0.29 & $(0.13,0.66)$ & 0.004 \\
\hline & $\geq 0.15 \mathrm{~m} / \mathrm{s}$ & 84.9 & 45 & & & & & & \\
\hline \multirow{2}{*}{ Ventilation Size } & $<15 \%$ Floor Area & 55.9 & 33 & 0.98 & $(0.57,1.71)$ & 1 & & & \\
\hline & $\geq 15 \%$ Floor Area & 56.3 & 219 & & & & & & \\
\hline \multirow{2}{*}{ Air conditioner } & No & 47.7 & 62 & 0.61 & $(0.41,0.93)$ & 0.026 & 0.71 & $(0.46,1.08)$ & 0.109 \\
\hline & Yes & 59.7 & 190 & & & & & & \\
\hline \multirow{2}{*}{$\begin{array}{l}\text { Classroom } \\
\text { Capacity }\end{array}$} & $30-40$ person & 59.1 & 123 & 1.25 & $(0.86,1.81)$ & 0.294 & & & \\
\hline & $<30$ person & 53.8 & 129 & & & & & & \\
\hline \multirow{2}{*}{$\begin{array}{l}\text { Ratio of space } \\
\text { needs per person }\end{array}$} & $<2 \mathrm{~m}^{2} /$ person & 58.5 & 227 & 1.974 & $(1.14,3.43)$ & 0.021 & & & \\
\hline & $\geq 2 \mathrm{~m}^{2} /$ Person & 41.7 & 25 & & & & & & \\
\hline \multirow{2}{*}{ School location } & main roadside & 56.8 & 205 & 1.118 & $(0.69,1.79)$ & 0.729 & & & \\
\hline & residential area & 54.0 & 47 & & & & & & \\
\hline \multirow{2}{*}{ Breakfast behavior } & No & 65.0 & 13 & 1.469 & $(0.57,3.75)$ & 0.564 & & & \\
\hline & Yes & 55.8 & 239 & & & & & & \\
\hline \multirow{2}{*}{$\begin{array}{l}\text { Drinking water } \\
\text { behavior at school }\end{array}$} & No & 63.6 & 82 & 1.529 & $(1.00,2.33)$ & 0.047 & & & \\
\hline & Yes & 53.3 & 170 & & & & & & \\
\hline
\end{tabular}


The multivariate analysis indicated that four variables were significantly associated with fatigue, namely sex, temperature, relative humidity, and air flow. While the variable air conditioner acted as the controlling variable. The results of multivariate analysis found that the OR value of the temperature variable was 2.25 , meaning that students who occupied a room with temperature more than $28^{\circ} \mathrm{C}$ would risk fatigue 2.25 times higher than students who occupied a room with temperature less than $28^{\circ} \mathrm{C}$, after being controlled by sex, relative humidity, air flow, and air conditioner variables. Mean while the most dominant variable related to the occurrence of fatigue among students was the sex variable. No substantial interactions were found between the related variables.

\section{Discussion}

An ideal classroom is a room that is comfortable and has a temperature of $18-28{ }^{\circ} \mathrm{C}$. Whereas a room with a temperature more than $28{ }^{\circ} \mathrm{C}$ has the risk of developing discomfort, sweat and stuffy feeling, due to heat that arise with the increasing room temperature. Statistically, the results shown in (Table 3 ) prove that there is a significant relationship between room temperature more than $28^{\circ} \mathrm{C}$ and the level of fatigue among students $(\mathrm{p}=0.008)$. While the value of OR 2.24, indicates that students who study in a room with a temperature more than $28^{\circ} \mathrm{C}$ has a chance of 2.24 times more exhausted compared to those who study in a room with a temperature of $18-28{ }^{\circ} \mathrm{C}$. This result is in accordance with the results of a study on workers which stated that increasing the air temperature to $28^{\circ} \mathrm{C}$ or above could reduce workers' performance by a minimum of $1.5 \%$ during both seasons ${ }^{23}$. According to the research conducted in India, classroom temperature can be accepted by $85 \%$ of students in the range of 26.9 $30.8^{\circ} \mathrm{C}$, with a comfortable temperature of $29^{\circ} \mathrm{C}^{24}$. The operating temperature of the room favored by students in Australia is $22.5^{\circ} \mathrm{C}$, but in summer, the room temperature ranges from $19.5^{\circ} \mathrm{C}$ to $26.6^{\circ} \mathrm{C}^{25}$. Based on the study of human muscle contractionsat different temperatures in ischemic conditions, greater levels of fatigue and faster onset was found at $37^{\circ} \mathrm{C}$ compared to $22^{\circ} \mathrm{C}^{26}$.

Maintaining adequate ventilation and thermal comfort in classrooms could significantly improve academic achievement of students ${ }^{27}$. Comfortable temperature depends on the value of relative humidity and air flow ${ }^{11}$. Most people feel comfortable when indoor air temperature is between $20^{\circ} \mathrm{C}$ and $27^{\circ} \mathrm{C}$ and relative humidity ranges between $35 \%$ and $60 \%$. Relative humidity is the amount of water vapor contained in the air-water mixture in the gas phase. Classrooms with relative humidity above $60 \%$ statistically have a significant relationship with fatigue among students. This study is consistent with previous studies that show most students feel tired (97.2\%), have a lower concentration (96.8\%) and feeling drowsy (94.1\%) for at least one hour each day when the room temperature is $\geq 32^{\circ} \mathrm{C}^{28}$. A study ${ }^{29}$ found that the most common weekly symptom felt by students as a result of poor indoor environmental quality (IEQ) is fatigue $(7.7 \%)$, nasal congestion $(7.3 \%)$, and headache $(5.5 \%)^{29}$. IEQ factors most frequently reported to cause daily discomfort in the classroom is noise $(11.0 \%)$ stuffy air/bad indoor air quality (IAQ) (7.0\%) temperature and rate of ventilation of the room.

The lack of air circulation in classrooms leads to an increase in temperature. High temperature causes discomfort and contributes to fatigue. This is proven by the discovery of a significant relationship between the rates of air circulation with fatigue. These results are consistent with previous article stating some short-term illness that can happen due to poor indoor air quality, including fatigue, poor concentration, nausea, loss of focus and memory disorders ${ }^{30}$. Researchers also have been investigating the relationship between indoor air quality and important issues not traditionally thought of as related to health, such as student performance in the classroom and productivity in occupational settings $\frac{31,32}{}$.

Our study shows that sex is associated with fatigue among students. This study is consistent with earlier studies regarding fatigue prevalence that have reported women have higher fatigue levels than men ${ }^{33,34}$. In contrast to our present results, earlier studies generally report more fatigue with advancing age ${ }^{35,36}$. Physical activity is related to fatigue. Graded exercise therapy has proven useful in the treatment for some forms of chronic fatigue syndrome $\frac{37,38}{}$. The lack of physical activity can partly express itself as fatigue. On the other hand, a fatigued person is probably less likely to be physically active for the apparent reason that fatigue negatively influences vitality and motivation ${ }^{39}$.

Health dangers related to poor indoor air quality can be treacherous and in stern cases, fatal. Both adults and children who are exposed to these lethal air surroundings in schools are prone to exhibiting physical signs associated to poor indoor air quality. Nevertheless, the effects of poor indoor air quality on children's health might be 
more adverse than it is to the grownups. Children have weaker health defense mechanism than adults. Therefore, their body would not withstand poor indoor air quality challenges on health ${ }^{40}$. Schools can use the source control strategy, with effective and inexpensive approach that seeks to eliminate sources of pollution. Another strategy that can be used by schools is improving ventilation systems to assist in regulating the circulation of air in classrooms. Schools can also use air purifier to improve indoor air quality. Air purifier helps eliminate airborne pollutants from the air conditioning pollutants.

\section{Conclusion}

The most important finding of this study was that there was a strong relationship between physical environment variables (air conditioning, temperature, relative humidity, ratio of space requirements per person and air flow) and the incidence of fatigue among private high school students in Bogor Tengah sub-district. The most related indicators to fatigue among students was sex. There is an interaction between sex and air conditioner variables on fatigue, this can be the basis in determining the type of air conditioner based on student sexratio. There is no meaningful relationship between breakfast behavior and water consumption behavior at school with the occurrence of fatigue among private high school students in Bogor Tengah sub-district.

\section{Ethical Clearance}

This study used biological subject, which was human. The number of ethical approval was made by the ethical research committee from National Institute of Research and Development. The number is LB.02.01/5.2/ KE.007/2016.

\section{Conflict of Interest}

The authors declare no conflict of interest.

\section{Acknowledgement}

Thank you to the Head of the National Institute of Research and Development who has provided financial support and guidance in the implementation of this research.

\section{References}

1. Saraiva TS, de Almeida M, Bragança L, Barbosa MT. Environmental comfort indicators for school buildings in sustainability assessment tools. Sustain. 2018; https://doi. org/10.3390/su10061849.

2. Giuli V De, Da O, Carli M De. Indoor environmental quality and pupil perception in Italian primary schools. Build Environ. 2012; 56: 335-45. https://doi.org/10.1016/j. buildenv.2012.03.024.

3. Mumovic D, Palmer J, Davies M, Orme M, Ridley I, Oreszczyn T, et al. Winter indoor air quality, thermal comfort and acoustic performance of newly built secondary schools in England. Build Environ. 2009; https://doi. org/10.1016/j.buildenv.2008.06.014

4. Aghamolaei T, Shirazi M, Dadgaran I, Shahsavari $H$, Ghanbarnejad A. Health students' expectations of the ideal educational environment: a qualitative research. J Adv Med Educ Prof. 2014.

5. Divaris K, Barlow PJ, Chendea SA, Cheong WS, Dounis A, Dragan IF, et al. The academic environment: The students' perspective. Eur J Dent Educ. 2008. https://doi.org/10.1111/ j.1600-0579.2007.00494.x. PMid:18289275.

6. Fadeyi MO, Alkhaja K, Sulayem M Bin, Abu-Hijleh B. Evaluation of indoor environmental quality conditions in elementary schools' classrooms in the United Arab Emirates. Front Archit Res. 2014. https://doi.org/10.1016/j. foar.2014.03.001.

7. Lee YC, Chien KL, Chen HH. Lifestyle risk factors associated with fatique in graduate students. J Formos Med Assoc. 2007; 106(7): 565-72. https://doi.org/10.1016/ S0929-6646(07)60007-2.

8. Ely MR, Ely BR, Cheuvront SN, Kenefick RW, Montain SJ, DeGroot DW. Evidence against a $40^{\circ} \mathrm{C}$ core temperature threshold for fatigue in humans. J Appl Physiol. 2009. https:// doi.org/10.1152/japplphysiol.00577.2009. PMid:19713430

9. Government Regulations. Number 32 of 2013: Amendment to Government Regulation Number 19 of 2005 concerning National Education Standards. Ministry of State Secretariat RI Indonesia. 2013.

10. Kim J, de Dear R. Thermal comfort expectations and adaptive behavioural characteristics of primary and secondary school students. Build Environ. 2018. https:// doi.org/10.1016/j.buildenv.2017.10.031.

11. Kuru M, Calis G. Understanding the Relationship between Indoor Environmental Parameters and Thermal Sensation of users Via Statistical Analysis. In: Procedia Engineering. 2017. https://doi.org/10.1016/j.proeng.2017.08.011.

12. Lbu ADA, Răcană IRC, Rejbeanu ILP. Study of School Fatigue on a Group of Teenagers Studying at "Dimitrie Cantemir" High school, Iaşi. Curr Heal Sci J. 2014; 40(3): 195-99. 
13. Bhaduri A. Fatigue. Springer Ser Mater Sci. 2018; 264(2014): 317-71. https://doi.org/10.1007/978-981-10-7209-3_8.

14. Tarwaka. Industrial Ergonomics, Knowledge Basics and Applications at Work. 2nd edition. Ergonomi Industri. Surakarta: Harapan Press; 2015.

15. Marcora SM, Staiano W, Manning V, Thom NJ, Johnson DC, Flagan T, et al. Mental fatigue impairs physical performance in humans activation during emotion processing in elite adventure racers Mental fatigue impairs physical performance in humans. 2009; 106(3):857-64. https://doi. org/10.1152/japplphysiol.91324.2008. PMid:19131473.

16. Tarwaka. Occupational Safety and Health, Management and implementation of Occupational Health and Safety at work. In: Surakarta: Harapan Press. 2014.

17. Fukuda S, Yamano E, Joudoi T, Mizuno K, Tanaka M, Kawatani J, et al. Effort-reward imbalance for learning is associated with fatigue in school children. Behav Med. 2010; $\quad$ https://doi.org/10.1080/08964281003774919. PMid:20497943.

18. Astuti RD, Tarwaka, Darnoto S. Effect of Music Work on Fatigue and Work Productivity of Filling Unit Employees at PT. Indo Acidatama Tbk. Kemiri, Kebakramat, Karanganyar. Univ Muhammadiyah Surakarta. 2014.

19. Mizuno K, Tanaka M, Fukuda S, Imai-matsumura K. Relationship between cognitive functions and prevalence of fatigue in elementary and junior high school students. Brain Dev. 2011; 33(6): 470-79. https://doi.org/10.1016/j. braindev.2010.08.012. PMid: 20846803.

20. BSN. SNI 03-6572-2001: Procedures for designing ventilation and air conditioning systems in buildings. 2001; 1-55.

21. BSN. SNI-6197-2011 Energy conservation in lighting systems. 2011.

22. ASHRAE. ASHRAE STANDARD 55 - 2010 Thermal Environmental Conditions for Human Occupancy. Ashrae Standard. 2010.

23. Kameni Nematchoua M. Analysis of some Physical Parameters under Workers \& apos; Optimal Performance in Wet and Hot Tropical Climates; A Literature Review. Am J Chem Eng. 2019. https://doi.org/10.11648/j. ajche.20180605.11.

24. Vittal R. Perceived Thermal Environment of NaturallyVentilated Classrooms in India. Creat Sp. 2017. https://doi. org/10.15415/cs.2016.32010

25. De Dear R, Kim J, Candido C, Deuble M. Adaptive thermal comfort in Australian school classrooms. Build Res Inf. 2015. https://doi.org/10.1080/09613218.2015.99 1627.

26. De Ruiter CJ, De Haan A. Temperature effect on the force/ velocity relationship of the fresh and fatigued human adductor pollicis muscle. Pflugers Arch Eur J Physiol. 2000. https://doi. org/10.1007/s004240051035. PMid:10864011.

27. Haverinen-Shaughnessy U, Shaughnessy RJ. Effects of classroom ventilation rate and temperature on students' test scores. PLoS One. 2015. https://doi.org/10.1371/journal. pone.0136165. PMid:26317643, PMCid: PMC4552953.

28. Bidassey-Manilal S, Wright CY, Engelbrecht JC, Albers PN, Garland RM, Matooane M. Students' perceived heat-health symptoms increased with warmer classroom temperatures. Int J Environ Res Public Health. 2016. https://doi. org/10.3390/ijerph13060566. PMid: 27338423, PMCid: PMC4924023.

29. Turunen M, Toyinbo O, Putus T, Nevalainen A, Shaughnessy $\mathrm{R}$, Haverinen-Shaughnessy $\mathrm{U}$. Indoor environmental quality in school buildings, and the health and wellbeing of students. Int J Hyg Environ Health. 2013. https://doi. org/10.1016/j.ijheh.2014.03.002. PMid: 24709335.

30. Mendell MJ, Heath GA. Do indoor pollutants and thermal conditions in schools influence student performance? A critical review of the literature. Indoor Air. 2005. https://doi. org/10.1111/j.1600-0668.2004.00320.x. PMid: 15660567.

31. U.S. Environmental Protection Agency. Indoor air quality and student performance. Washington, DC.; 2003.

32. Stafford TM. Indoor air quality and academic performance. J Environ Econ Manage. 2015. https://doi.org/10.1016/j. jeem.2014.11.002

33. Fieo RA, Mortensen EL, Lund R, Avlund K. Assessing Fatigue in Late-Midlife: Increased Scrutiny of the Multiple Fatigue Inventory-20 for CommunityDwelling Subjects. Assessment. 2014. https://doi. org/10.1177/1073191114541143, PMid: 24986784.

34. Basu N, Yang X, Luben RN, Whibley D, Macfarlane GJ, Wareham NJ, et al. Fatigue is associated with excess mortality in the general population: Results from the EPIC-Norfolk study. BMC Med. 2016. https://doi.org/10.1186/s12916016-0662-y. PMid: 27543008, PMCid: PMC4992307.

35. Schwarz R, Krauss O, Hinz A. Fatigue in the general population. Onkologie. 2003. https://doi.org/10.1159/ 000069834. PMid: 12771522.

36. Watt T, Groenvold M, Bjorner JB, Noerholm V, Rasmussen NA, Bech P. Fatigue in the Danish general population. Influence of sociodemographic factors and disease. J Epidemiol Community Health. 2000.https://doi.org/10.1136/ jech.54.11.827. PMid: 11027196, PMCid: PMC1731588.

37. Perry SE, Santhouse AM. Chronic fatigue syndrome. Medicine (United Kingdom). 2016. https://doi. org/10.1016/j.mpmed.2016.09.015

38. Castell BD, Kazantzis N, Moss-Morris RE. Cognitive behavioral therapy and graded exercise for chronic fatigue syndrome: A meta-analysis. Clin Psychol Sci Pract. 2011. https://doi.org/10.1111/j.1468-2850.2011.01262.x. 
39. Engberg I, Segerstedt J, Waller G, Wennberg P, Eliasson M. Fatigue in the general population- associations to age, sex, socioeconomic status, physical activity, sitting time and selfrated health: the northern Sweden MONICA study 2014. BMC Public Health. 2017. https://doi.org/10.1186/s12889017-4623-y. PMid: 28806984, PMCid: PMC5557471.
40. Yang W, Sohn J, Kim J, Son B, Park J. Indoor air quality investigation according to age of the school buildings in Korea. J Environ Manage. 2009. https://doi.org/10.1016/j. jenvman.2007.10.003. PMid: 18079045. 